\section{New distributional record of Gentiana tetrasepala Biswas (Gentianales: Gentianaceae) from the Valley of Flowers National Park, Garhwal Himalaya}

\author{
C.S. Rana ${ }^{1}$, V. Rana $^{2}$ \& M.P.S. Bisht ${ }^{3}$ \\ ${ }^{1}$ State Medicinal Plants Board Uttarakhand, Dehradun, \\ Uttarakhand 248006, India, \\ ${ }^{2,3}$ Department of Geology, HNB Garhwal University, Srinagar \\ (Garhwal), Uttarakhand 246174, India \\ Email: 1drcsir@gmail.com (corresponding author), \\ 22virendrarana3@yahoo.co.in, ${ }^{3}$ mpbisht@gmail.com
}

Endemic plants are more prone to extinction for various reasons as they are habitat specific. Because of unstable habitats, in a small area with a limited population they are extra stressed. Therefore, such endemics must be prioritized for conservation efforts (Rawat 2009). Considering this, we have been trying to locate the populations of alpine endemics in the Garhwal Himalaya and succeeded in rediscovering Arenaria curvifolia Majumdar after 121 years (Rawat \& Rana 2007) and Dicranostigma lactucoides Hk. f. et Thoms. after 150 years (Rawat et al. 2009). After our recent floristic survey in relation to glacial recession and the upward shift of the vegetation at the alpine

Date of publication (online): 26 September 2011 Date of publication (print): 26 September 2011 ISSN 0974-7907 (online) | 0974-7893 (print)

Editor: K.S. Negi

\section{Manuscript details:}

Ms \# o2572

Received 15 September 2010

Final received 29 April 2011

Finally accepted 10 August 2011

Citation: Rana, C.S., V. Rana \& M.P.S. Bisht (2011). New distributiona record of Gentiana tetrasepala Biswas (Gentianales: Gentianaceae) from the Valley of Flowers National Park, Garhwal Himalaya. Journal of Threatened Taxa 3(9): 2100-2103.

Copyright: (c) C.S. Rana, V. Rana \& M.P.S. Bisht 2011. Creative Commons Attribution 3.0 Unported License. JoTT allows unrestricted use of this article in any medium for non-profit purposes, reproduction and distribution by providing adequate credit to the authors and the source of publication.

Acknowledgements: The authors are grateful to Dr. G.S. Rawat Wildlife Institute of India, Dehradun for going through the manuscript and constructive criticism and to Dr. R.C. Sundriyal, Director Herbal Research \& Development Institute, Mandal-Gopeshwar, Chamoli for providing laboratory facilities.

\section{OPEN ACCESS | FREE DOWNLOAD}

meadows of the Valley of Flowers National Park (VoFNP) (Image 1), we report here the recollection

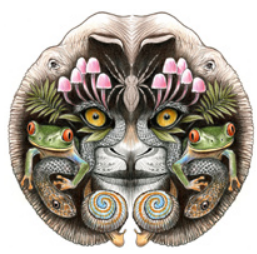
of Gentiana tetrasepala Biswas along with the causes of recent threats and the high need of conservation.

Gentiana tetrasepala was described by Biswas in 1938 on the basis of specimens collected by J.F. Duthie (No. 3166 CAL) from Ralam Valley (Kumaon Garhwal) on 26 August 1884. Since then the species was never recorded leading to the general assumption that the species had either become extinct or is not a distinct and taxonomically valid species (Garg 1987). Chowdhery \& Murti (2000) mentioned this species among the red taxa as per IUCN's criteria of red taxa (IUCN 1994). It was placed under the 'IK' (insufficiently known) category as per the Indian Red Data Book (Nayar \& Shastry 1987). Rawat (2009) suggested that it be placed under the category 'I' (indeterminate). This species has a restricted geographical range (one small population in the alpine zone of VoFNP, Chamoli District, Uttarakhand). It has a very habitat-specific occurrence and seems partially affected by the recent upward shifting of the vegetation due to global warming and regional climatic variations. More recently, Rawat (2009) re-discovered this species from Madhu Ganga Valley in Kedarnath $(4700 \mathrm{~m})$ in Rudarprayag District after a long gap of 123 years. Our specimen (CSR-GUH 19587) collected from Kunth Khal (3800m) (Image 2) above Bhyundar Ganga (Garhwal Himalaya) in August 2009 suggests a wider range and protection in a World Heritage Site (VoFNP) unlike the population recorded by Rawat (2009) in a highly disturbed site. The voucher specimens are

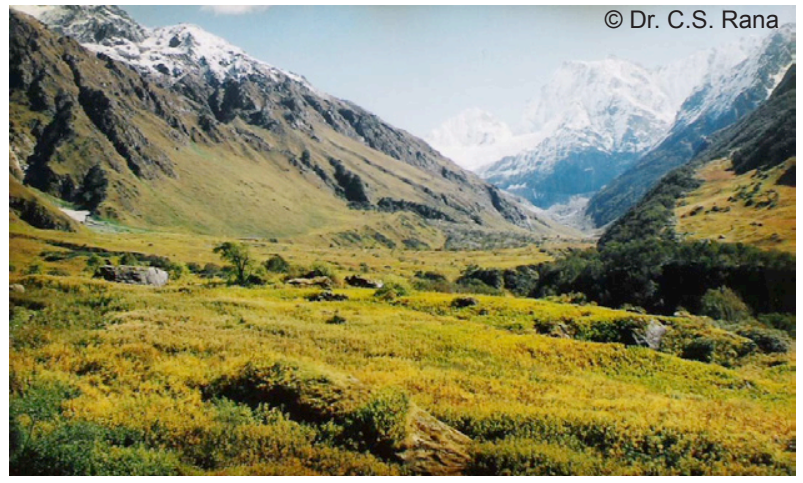

Image 1. Wide view of Valley of Flowers National Park 


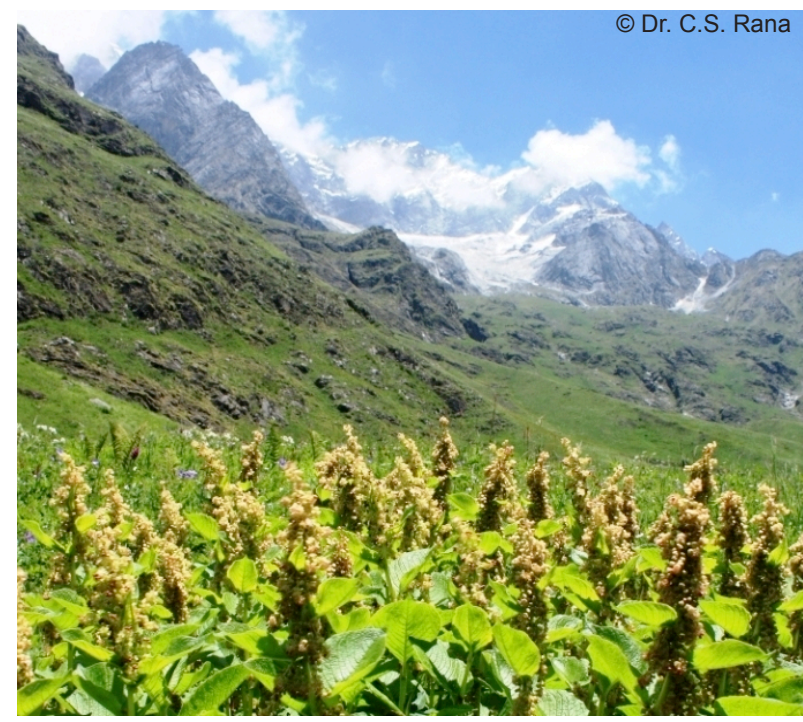

Image 2. Kunth Khal (Habitat of Gentiana tetrasepala)

deposited at the Herbarium of Garhwal University (GUH), Srinagar, Garhwal and Pantanagar University Herbarium (PUH) (441/2) (Image 3). The present collection outside the type locality (Barjikang Pass in Ralam Valley of Kumaon Garhwal) indicates a wider range of distribution, though it is still an endemic of the Uttarakhand Himalaya. The noticeable threats to its survival (i) and potential threats (ii, iii) are:

(i) Invasion of timberline species i.e. Selinum vaginatum (Edgew.) C.B. Clarke, Solidago virgaurea L., Dactylorhiza hatagirea (D. Don) Soo, Geranium wallichianum D. Don ex Sweet, Picrorhiza kurrooa Royle ex Benth., Potentilla atrosanguinea Lodd. ex Lehm, Anaphalis triplinervis (Sims.) C.B. Clarke, Malaxis cylindrostachya O. Kuntze, Meconopsis aculeata Royle, Saxifraga stenophylla Royle, and Stellaria decumbens Edgew. towards permanent snowline (Rana et al. 2010).

(ii) Inevitable replacement of habitat in unstable reducing glacial cover and snow covers.

(iii) Global warming and regional climate change induced upward shift of sub-alpine flora which produce habitat replacement.

Korner (1999) strongly suggested a similar consequential stress on alpine vegetation. Global warming and micro-climatic changes are known to induce upward range shift (some times downward) of the plant species (Grabher et al. 1994; Grace et al. 2002; Parmesan \& Yohe 2003; Dubey et al. 2003; Lenior et al. 2008; Xu et al. 2009; Rana et al. 2010).

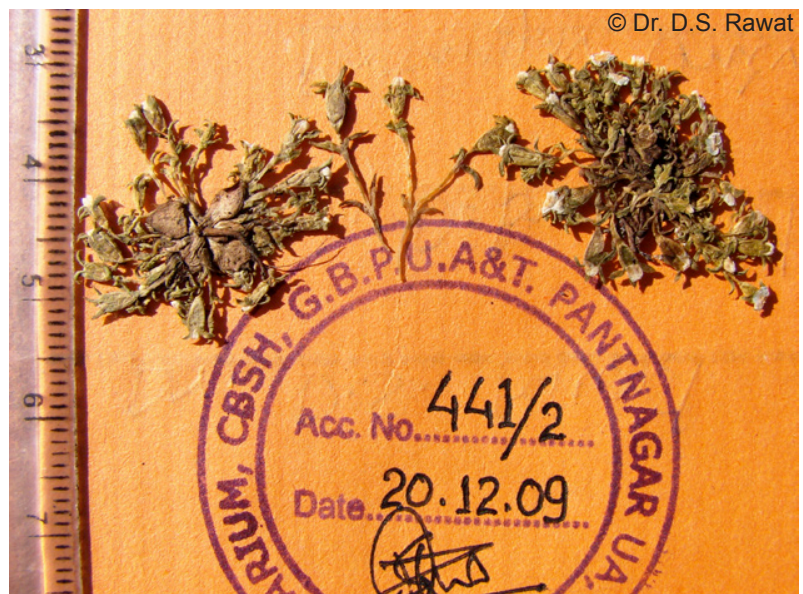

Image 3. Gentiana tetrasepala Biswas

If, the aforesaid reference trends are applied to only the well known protected population (habitat) of $G$. tetrasepala it will certainly disappear within the next few decades. The reason being that it is an obligatory seeder (annual) and is restricted to open high elevation terrain and it exhibits fast responses to climatic variation i.e. upward shift of the alpine plant species (Rana et al. 2010). G. tetrasepala occupies sparsely vegetated stable slopes where ample open spaces are available for seeds to reach the soil level and germinate (Rawat 2009). However, rising temperatures, longer season length, and increased $\mathrm{N}_{2}$ supply alone or in combination will open the alpine terrain for invaders from lower elevations and create pressure for an upward shift of alpine plant species towards the snowline (Rana et al. 2010). In such cases the existing habitat will allow other species from the lower alpine slopes to occupy available spaces making it a close vegetated slope. Consequently, G. tetrasepala will be eliminated due to unavailable open spaces at existing altitudes (Rawat 2009). Simultaneously, an upward shift is also possible in this terrain where the area is meadow and it is likely that soil will be available there even after half a century due to the recent disappearance of glacial mass, volume, area and length (Mehta et al. 2011). The area where a population is located in the debris slide zone was earlier a grazing land of local livestock, which is now conserved. These few hundred plants of the species protected from anthropogenic pressure are at risk from upwards shifting of the alpine plant species (Grabher et al. 1994; Grace et al. 2002; Dubey et al. 2003; Parmesan \& Yohe 2003; Lenoir et al. 2008; 


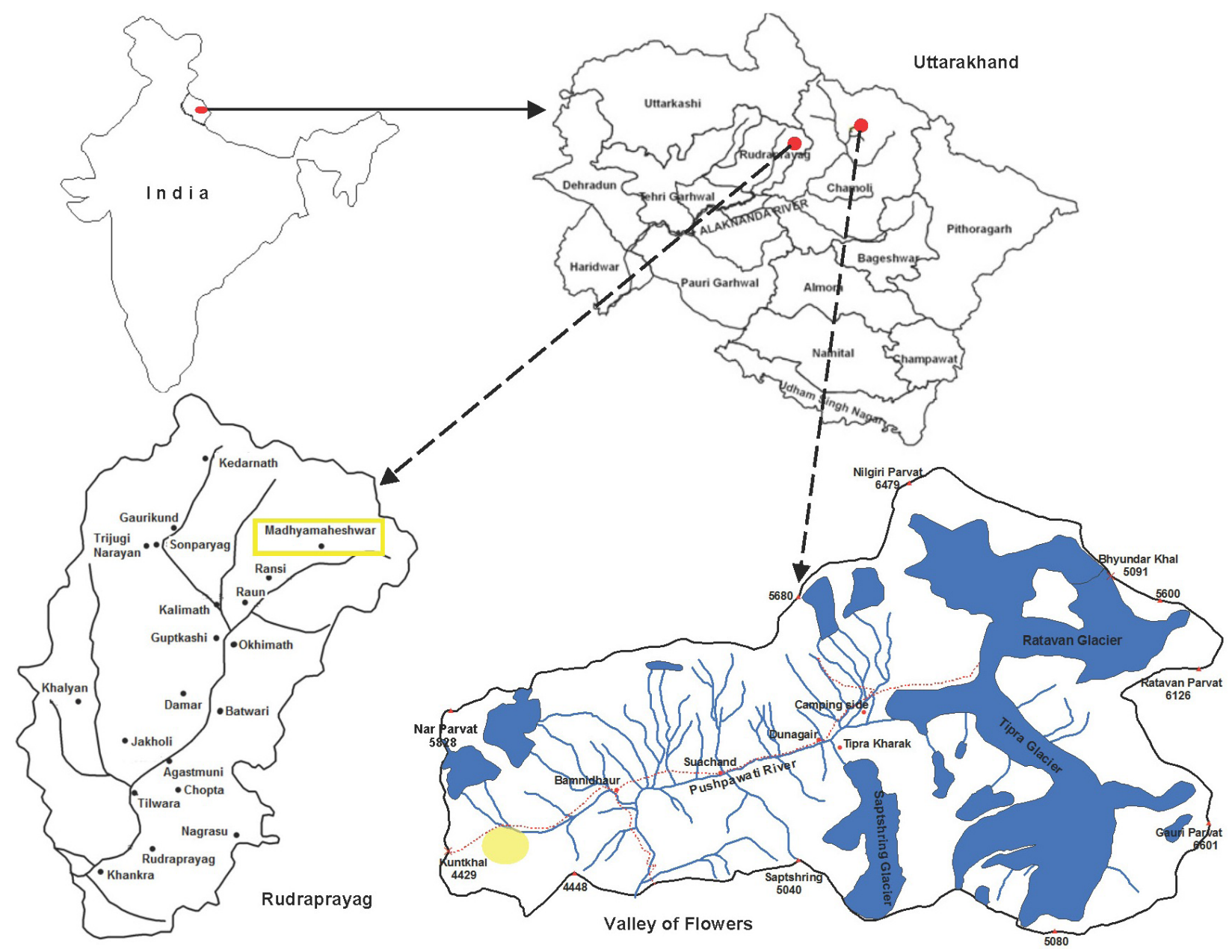

Image 4. Map showing current distribution record of Gentiana tetrasepala

Xu et al. 2009; Rana et al. 2010).

Considering a single extant population of few hundred individuals, the annual nature of the species, the severity of unpredictable climate and the stress posed by the upward shift of sub-alpine flora due to the recent climatic and glacial variations, its status must be reassessed as it is threatened. The present habitat of G. tetrasepala has provided an opportunity for its conservation but at the same time further studies need to be carried out with concerns of recent environmental changes and habitat replacement in the Valley of Flowers National Park.

Gentiana tetrasepala Biswas in Hk. f. Ic. Plant 4: ser.5.t. 3359. 1938; Garg, Gentianaceae of Northwest Himalaya, 107, 1987; Rawat, Nat. Acad. Sci. Lett. 169-172. 2009.

A tiny, glabrous, annual, alpine herb, 0.8-3 $\mathrm{cm}$ across. Root slender, filiform, branched. Stem branched at base; diffuse, $0.5-1 \mathrm{~cm}$ long, ascending in flowering, prostrate in fruit, glabrous, thin, greenish. Leaves radical 2-3 pairs, leaves of lowermost pair rounded to obovate-spathulate, cauline leaves obovate to pandurate, $2-5 \times 1.5-3 \mathrm{~mm}$; elliptic-lanceolate, entire, mucronate, recurved, glabrous, $1.5-2.0 \times 2-4$ $\mathrm{mm}$, sessile. Flowers solitary, terminal on branches, pedicellate, 4-merous, 2-4 $\mathrm{mm}$ long, greenish. Calyx lobes four, 2-4 mm long, green, tube 2-2.5 $\mathrm{mm}$, constricted at the upper end, lobes spreading, dissimilar, reflexed in fruit, ovate to lanceolate, 1-1.5 $\mathrm{mm}$ long, margins scarcely cartilaginous, entire, glabrous, acute. Corolla dull-white, shorter than calyx but slightly exceeding calyx tube, elliptic, 2-3.5 $\mathrm{mm}$ long, 4 lobed, lobes erect, very small, scarcely exceeding $0.5 \mathrm{~mm}$, entire, obtuse or rounded, plicae broadly triangular, slightly smaller than corolla lobes, incised or bidentate, acute. Stamens four, very small, inserted on the middle of corolla tube, filaments as long as or shorter than anther, filiform, $0.5-1 \mathrm{~mm}$; anther 
ovate-oblong, included in corolla tube. Ovary elliptic or obovate, $1-1.5 \times 2-3 \mathrm{~mm}$, shortly stipitate, with orange-yellow nectariferous ring at base; style short, slender; stigma with two partially circinate lobes. Fruit a capsule with 3-7 mm long stipe, exserted of corolla tube at maturity, $3 \times 4 \mathrm{~mm}$, obovate, opening halfway down only, halves reflexed. Seeds brown, ovate-oblong, $1 \times 0.75 \mathrm{~mm}, 15-25$ per capsule.

Flowering and fruiting: July-October.

\section{REFERENCES}

Chowdhery, H.J \& S.K. Murti (2000). Plant Diversity and Conservation in India - An Overview. Bishen Singh Mahendra Pal Singh, Dehradun, 303pp.

Dubey, B.R., J, Yadav, R. Singh \& Chaturvedi (2003). Upward shift of Himalayan Pine in Western Himalaya, India. Current Science 85: 1135-1136.

Garg, S. (1987). Gentianaceae of Northwest Himalaya: A Revision. Today and Tomorrow's Printing \& Publication, New Delhi, 342pp.

Grabher, G., M. Gottfried \& H. Pauli (1994). Climate effects on mountain plants. Nature 369: 448.

Grace, J., F. Berninger \& L. Nagy (2002). Impact of climate change on the tree line. Annals of Botany 90: 537-544.

IUCN (1994). Red list categories. Prepared by the IUCN Species Survival Commission. ICUN, Gland, Switzerland.

Korner, C. (1999). Alpine Plant Life. Berlin: Springer-Verlag. Lenoir, J., J.C. Gegout, P.A. Marquet, P. Ruffray \& H.
Brisse (2008). A significant upward shift in plant species optimum elevation during the $20^{\text {th }}$ century. Science 320 : 1768-1771.

Mehta, M., D.P. Dobhal \& M.P.S. Bisht (2011). Change of Tipra glacier in the Garhwal Himalaya, India, between 1962 and 2008. Progress in Physical Geography DOI No: 10.1177/0309133311411760.Page No. 1-18.

Nayar, M.P. \& A.R.K. Shastry (1987). Red Data Book of Indian Plants. Vol. I. Botanical Survey of India, Calcutta, $367 \mathrm{pp}$.

Parmesan, C. \& G.A. Yohe (2003). Globally coherent fingerprint of climate change impacts across natural systems. Nature 421: 37-42.

Rana, C.S., V. Rana \& M.P.S. Bisht (2010). An unusual composition of the plant species towards zone of ablation (Tipra glacier), Garhwal Himalaya. Current Science 99: 574-577.

Rawat, D.S., H. Singh \& C.S. Rana (2009). New distributional records of Dicranostigma lactucoides and Dipcadi serotianum from Uttaranchal. Journal of Economic and Taxonomic Botany 33: 32-34.

Rawat, D.S.\& C.S. Rana (2007). Arenaria curvifolia Majumdar (Caryophyllaceae): an endangered and endemic Himalayan herb rediscovered. Current Science 92: 1486-1487.

Rawat, D.S. (2009). A presumed extinct endemic alpine herb Gentiana tetrasepala rediscovered after 123 years: will it survive? National Academy Science Letters 32: 169-172.

Xu, J., G.R. Edward, A. Shrestha, M. Eriksson X. Yang, Y. Wang \& A. Wilkes (2009). The melting Himalayas: cascading effects of climate change on water, biodiversity and livelihoods. Conservation Biology 23: 520-530. 